wrappings to the armour (or lead as the case may be), painting the cable with bitumen paint, wrapping with a layer of bituminized tape and then applying two layers of asbestos tape with a sensible overlap. The asbestos should be freely painted with silica paint.

For a number of years the research staffs of the associated firms of cable makers have been attempting to produce fire-resisting or self-extinguishing rubber compounds, and a fair degree of success has been obtained in imparting these properties to rubber. The fundamental difficulty has been that raw rubber is not self-extinguishing when once ignited, and the other materials which it is necessary to incorporate in the 'mix' to overcome the lack of self-extinguishing properties greatly modify its other desirable properties.

A new synthetic material has been discovered which belongs to the same general chemical group as rubber. This material in its raw state is very similar in its physical properties to raw rubber. It is converted into a suitable 'mix'. As, however, the material is fire-resisting, it is not necessary to obtain the fire resistance at the expense of other properties.
Extensive tests have shown that this synthetic material is more resistant than rubber to deleterious influences.

Fires which have occurred in coal mines during recent years with deplorable loss of life raised the question in some minds as to how far electrical cables have been responsible for either initiating a fire or conveying an existing fire from one part of a mine to another. At the instigation of Mr. Horsley, electrical inspector of mines, the cable makers agreed to carry out experiments with the view of obtaining data which would answer certain specific questions. It was found that the application of a hot external flame for about 15 seconds was necessary to ignite the compound on the wrappings of a standard C.M.A. cable; hence it does not seem probable that such wrappings around the cable would be ignited as the result of a transient flame such as would arise, for example, from an explosion of fire damp. The experiments also showed that the armour wires practically completely protected the inside of the cable. The cable makers have to be congratulated on the way they have co-operated in very expensive researches for their mutual benefit.

\title{
NEW INTERNATIONAL COMMISSION OF SNOW AND GLACIERS
}

\author{
By F. E. Matthes
}

\begin{abstract}
A T the Seventh Assembly of the International Union of Geodesy and Geophysics, which was held in Washington last September, the International Association of Scientific Hydrology, one of the component units of the Union, effected the consolidation of two of its own commissions--the Commission of Snow and the Commission of Glaciers. The action was taken after a preliminary poll of the membership of the two commissions had shown an overwhelming majority in favour of the consolidation. Moreover, the presidents of both commissions, Prof. J. E. Church, of the University of Nevada, U.S.A. (snow), and Mr. J. M. Wordie, of St. John's College, Cambridge, Britain (glaciers), had strongly recommended it.

Prof. Church was designated acting president of the new Commission of Snow and Glaciers, to serve in that capacity until international relations will permit the holding of a formal election of officers. Like all other sections of the International Union of Geodesy and Geophysies, the Association of Hydrology has deferred election of officers for the present triennial period, in view of the sparse attendance of European delegates at the Washington assembly, due to war conditions.

The new Commission of Snow and Glaciers aims at taking into its purview all research relating to snow and ice in their varied forms. It might appropriately have been named Commission of Snow and Ice, but it preferred to adopt the name Commission of Snow and Glaciers in deference to the former Commission of Glaciers, which is by far the older of the two bodies that are now consolidated, and which, indeed, was in existence long before the Association of Hydrology was formed.
\end{abstract}

The original Commission Internationale des Glaciers had its inception in 1894, at the International Geological Congress at Zurich. It was charged, broadly, with the task of studying existing glaciers throughout the world; but actually its efforts have been concentrated on securing statistics of the secular variations-advance and recession-of glaciers in response to climatic fluctuations. Inasmuch as this task requires the making of annual measurements on large numbers of glaciers in different countries, with the aid of co-operating agencies, governmental, scientific, and other, it has inevitably grown into a vast enterprise. The results, however, have proved of value, not only to glaciologists but also to hydrologists, hydraulic engineers (making use of run-off from glaciers for economic purposes), and climatologists.

In 1914 the work of the Commission was stopped by the war, and co-ordinated effort ceased for a number of years. In 1927, however, at the invitation of the International Association of Scientific Hydro$\log y$, the Commission transferred its functions and its personnel to a new Commission Glaciologique created by the Association, and under these new auspices its work has been carried on ever since.

Meanwhile, at the Lisbon assembly, in 1933, the Association set up a Commission of Snow and appointed Prof. Church president of it. So rapidly did this Commission grow under the enthusiastic leadership of its president that by 1936, when the Association met in Edinburgh, it had become by far the largest and most active of all the commissions of the Association and had extended its field to cover all phenomena of snow and ice, with the exception of glacier variations. Overlap with the work of the Commission of Glaciers seemed almost inevitable, 
and so the question naturally arose whether consolidation of the two commissions would not in the end be mutually advantageous to them. Their union was approved by the Executive Committee of the Association at its meeting in April 1939 at Montreux, Switzerland, and so the way was paved for its final consummation at the Washington assembly.

Provision has been made within the new Commission of Snow and Glaciers for a permanent Committee on Glacier Measurements, which will continue the work previously carried on by the Commission of Glaciers, securing systematic records of the annual variations of glaciers. It is Prof. Church's intention to expand the scope of that work, which heretofore was restricted largely to Europe and the United States, so as to take in all of the more important glacier districts of the world, including the Andes of South America, the great mountain chains of Asia, the Alps of New Zealand, and the Arctic regions.

Aside from this enterprise the Commission has planned for the triennium ending in 1942 the following formal programme :

(1) Study of the origin, drift, and dissolution of icebergs, with reference to the forecasting of their seasonal appearance.

(2) Physical changes in the snow-cover conducive to run-off, especially floods.

(3) Study of the crystalline texture of glacier-ice in relation to the mode of movement of glaciers.

In addition, the following four special projects have been assigned to temporary committees :

(a) Standardization of maps of snow-cover and ice-cover for the world.

(b) Uniform classification of different types of snow and snow-cover, and uniform nomenclature for the same.

(c) A system of classification for the international bibliography of snow and ice.

(d) Standardization of methods of snow-surveying and forecasting run-off from snow.

\section{TRAINING INDUSTRIAL WORKERS}

$\mathrm{I}^{\mathrm{N}}$ Occupational Psychology (14, No. 1), B. Ungerson discusses the important problem of the training of industrial workers. In spite of the improvement in methods of training learners during recent years, there are still numerous organizations where the only method of training is to let the beginner copy an experienced worker, or he is told what to do and left to get on as best he may.

The resulting efficiency frequently falls short of what he might have attained. It is strange that while it is recognized that games are best learned under the tuition and guidance of an experienced teacher, industrial processes are so frequently allowed to be 'picked up'.

Ungerson divides industrial training into two sections: (1) acquiring knowledge about the job; (2) acquiring facility and speed in making the necessary movements.

The first includes knowledge of technical terms, the tools to use, how to deal with unusual circum- stances; such knowledge can best be taught by a skilled teacher-not necessarily equivalent to the most skilled worker-whose primary business is teaching, not production, and who shall have the requisite qualities for teaching and be given adequate facilities.

In order to teach the correct movements the teacher should himself have a conscious knowledge of them, and for this, motion study is essential. By motion study knowledge is gained of the adequate and useless movements, so that the learner is instructed from the beginning in the right method, and thereby saved from having to unlearn unnecessary movements later.

The principles of motion study which are based on the physiology and psychology of habit formation are no longer a problem for research; it is their application that is needed.

The article is very well balanced and constructively critical, and is of immediate importance.

\section{'SPIKE' DISEASE OF SANDAL}

$\mathrm{F}^{\mathrm{on}}$ R many years after it was first reported in 1898 the so-called 'spike' disease of the sandal tree remained an enigma. Investigations were carried out in a desultory fashion, but no information of value resulted. It is only owing to its alarmingly rapid spread in many parts of the Madras Presidency and elsewhere in Mysore and Coorg that the work of the last few years has resulted in methods of control, the results of careful research work, being successfully elaborated and put into force.

In Indian F'orest Records (New Series. Silviculture, 3 , No. 7 ; 1939) appears a paper entitled "A Note on the Control and Eradication of New Outbreaks of the Spike Disease of Sandal (Santalum album)" by Rao Sahib S. Rangaswami and A. L. Griffith, Sylvi- culturist, Madras. The sandal, as is well known, is a root parasite which lives by haustorizing on the roots of other plants which act as hosts to it. These hosts may be many and varied, for the same sandal tree and the sandal haustoria may wander a considerable distance before a suitable host is found. The sandal tree is not necessarily parasitic on the plants growing nearest to it.

The action of the disease causes both new shoots and leaves to stand up stiff and bristle-like, from which the popular name was derived. The disease itself is a virus disease carried by insects which are probably between $1 / 20$ in. and $\frac{1}{4}$ in. in size. In a diseased area the sources of infection are $(a)$ diseased trees, $(b)$ disease masking trees, and $(c)$ insect vectors. 